\title{
The Role of Social Capital in the Process of Becoming an Entrepreneur and in Entrepreneurial Success
}

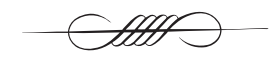

\begin{abstract}
The network approach plays an important role in the sociological study of enterprises and of the process of becoming an entrepreneur. In our analysis we examine the role of social relations in the setup process of enterprises by the aid of a questionnaire survey of 3,021 respondents representative of the adult population of Transylvanian small towns, and the impact of networks on business success based on the results of a questionnaire survey of 1,005 companies representative of Transylvanian small and medium-sized enterprises. The conclusion of our study is that social network as a resource is much more important during the setting up of an enterprise, whereas in the case of already established, operating enterprises its contribution to entrepreneurial success is less significant.
\end{abstract}

Keywords social networks, entrepreneur, enterprise, enterpreneurship

DOI 10.14232/belv.2016.2.3 http://dx.doi.org/10.14232/belv.2016.2.3

Cikkre való hivatkozás / How to cite this article: Kiss, Dénes (2016): The Role of Social Capital in the Process of Becoming an Entrepreneur and in Entrepreneurial Success. Belvedere Meridionale vol. 28. no. 2. 38-50. pp

ISSN 1419-0222 (print) ISSN 2064-5929 (online, pdf)

(Creative Commons) Nevezd meg! - Így add tovább! 4.0 (CC BY-SA 4.0)

(Creative Commons) Attribution-ShareAlike 4.0 International (CC BY-SA 4.0)

www.belvedere-meridionale.hu 
The network approach plays an important role in the sociological study of enterprises and of the process of becoming an entrepreneur. According to the basic concepts of the paradigm associated primarily with Aldrich's name, entrepreneurs, too, are actors embedded in social micro-contexts, networks, whose endeavours to become entrepreneurs may be facilitated or hindered by these networks (Zimmer 1986. 14). The role of social capital in becoming an entrepreneur has been studied primarily with regard to small enterprises, since the innovative combination, the "bricolage" (the corresponding Hungarian term introduced by Tibor Kuczi being "kreácsolás", Kuczi 2011) of readily available resources and of others, which may be mobilized through contacts, is more emphatic in their case. The establishment of an enterprise is thus at the same time an inherent networking activity (DUBINI - ALDRICH 1991. 306).

The synergy effect of social networks on the establishment process of an enterprise, as well as their beneficial influence on the success of already operating, consolidated businesses is a much studied phenomenon. As regards the establishment process of enterprises, these studies have identified several kinds of helping mechanisms social capital can activate. To mention only the most important ones: contacts may serve as a source of information, that is, as additional resources to complete formal information sources, they may provide access to clients and suppliers, moreover, a proper social network, since it may provide an informal way to obtain loans, will possibly strengthen the financial basis of a business, too (PowELL - SMITH-DoerR 1994. 372). A family network may also present specific advantages by providing unpaid (family) work; this may be particularly useful in the initial phase of establishing a business, when it might mitigate the initial financial constraints; it may reduce the efforts spent on controlling the employees, as well as ensure emotional support (provided by the spouse especially) in the processing of the frustrations emerging due to failures in the entrepreneurial process (SANDERS - NEE 1996).

One of the most detailed analyses of the impact of social networks on entrepreneurship has been carried out by Greve, who proposed to find out what are the most advantageous kinds of social networks in the different stages of the process of entrepreneurship. In order to examine this question, Greve distinguished among three stages in the process of founding a company. According to his model, the process starts with the ripening of a business idea, it continues with the organizational activity of setting up the business and finally, it ends with the initial stage of the operation of the newly created company. In the first phase thus, the individual becomes motivated on setting up the enterprise, and formulates some ideas in this regard, but does not take practical steps yet to achieve this goal (the motivation phase). In the second phase, the entrepreneur starts to plan the business in detail, to search funds, to set up arrangements, to look for a business establishment (the planning phase). Finally, the third phase of the process begins when the company starts the operating phase.

Since during these three phases the entrepreneur needs different resources, his/her contact network has to serve different purposes at every stage, and consequently this personal contact network undergoes a transformation during this process, its characteristics will be different in each phase. Using the sophisticated tools of network analysis, Greve has formulated several hypotheses regarding these changes in the social network:

In the course of the process of setting up an enterprise there is need for an ever growing web of contacts, and more and more work (confirmed)

The existence of a high-density social network is the most important in the planning phase. In the establishment phase a less dense contact network is preferable. (not confirmed)

The importance of indirect contacts increases in the establishment phase. (not confirmed) 
In the establishment phase the importance of bridging social capital increases (confirmed)

In the establishment phase the importance of work relationships increases, at the expense of family ties and friendships (not confirmed)

In the establishment phase the importance of relations with persons active in different professions, especially the ties formed with managers, increases (confirmed)

In the light of Greve's results thus, the social networks of entrepreneurs in different phases of entrepreneurship differ in extension, in the number of available bridging ties, as well as in the professional composition of the group belonging to the network (especially as regards the percentage of managers). These characteristics show a tendency of growth in the course of the history of the enterprise (GREVE 1995).

Research and analysis has not managed to clearly demonstrate the impact of social capital on already consolidated enterprises. Certain studies show a contrary pattern. BATES (1994), for instance, concluded that a more intense use of network resources is characteristic of companies lacking in other assets, and therefore more prone to bankruptcy. However, this correlation called the „compensation hypothesis” has not been verified by BRÜDERL and PREISENDÖRfER (1998), but the correlation termed „network success hypothesis," according to which extensive social networks based on strong bonds contribute to the success of newly established businesses, has been proven by them.

The role of personal relations in entrepreneurship was called even more radically into question by Curran and his colleagues, who concluded, on the basis of a qualitative research performed in the United Kingdom, that small-business owners/managers did not use the family contacts, kinship and friendship relations at their disposal for business purposes, not even in a tight situation. They were characterized instead by their preference to remain independent of these networks. This can be traced back primarily to their self-definition emphasizing independence, to the mentality according to which the enterprise may be conceived of as a kind of personal „fortress” (fortress-enterprise mentality), and the business is the entrepreneur's own, individual responsibility and duty.

Apart from the influence of this culture-specific (small) entrepreneurial identity, active participation in family and kinship-friendship networks was limited also because of the time consuming nature of networking. Forming contacts with experts and consultants was also unadvisable because of its expensiveness, since this latter type of relationships were moneycosting service contacts (CURRAN et al 1993).

According to Donckels and Lambrecht (Donckels - LAmbrecht 2005), too, family relationships have an obstructive influence on business success. These authors posit that the success of existing businesses is facilitated primarily by geographically extensive, businessrelated contact networks, but the positive impact of these contacts is limited/extinguished by the entrepreneur's strong embeddedness in family, kinship relationships. The results of the analysis ultimately did not verify this latter hypothesis. Instead, the researchers proved that although strong family bonds have an inhibiting effect on the development of international relations (by reducing the frequency of the entrepreneurs' participation in trade fairs/exhibitions, which promote the formation of this type of ties), they do not hinder the positive effects of already existing national and international relationships. It has been, however, clearly shown that geographically more extensive national and especially international social networks involving business people do bear a positive effect on the success of enterprises (DONCKELS - LAMBRECHT 2005). 


\section{The role of social networks in the process of entrepreneurship and in the entrepreneurial success of small entrepreneurs in Transylvania}

In our analysis we have also chosen to examine the impact of the entrepreneur's ego-centered network of contacts on setting up and successfully running a business. Having in view the process of entrepreneurship we are going to differentiate the phases proposed by Greve, introducing yet another phase in the process model: the phase of lack of motivation prior to the motivation phase. Although the entrepreneurship process starts obviously with the formulation of the idea, when it comes to the impact of different relationships on this process, the role of the future entrepreneur's personal social network, its characteristics and differences compared to the networks of those who do not come up with a business idea, cannot be regarded as incidental in taking the first steps toward the articulation of the business idea.

We have examined the effects of networks on the success of already operating businesses using three variables. One of them is the lifetime of enterprises; we considered the long life of a company one aspect of successful operation. Having in view the life span of enterprises, we may distinguish two phases: businesses in the initial and in the established phase, classifying into this latter type, after Pete and his coathors, the businesses that have been operating for longer than three and a half years (PETE et al. 2010). Since the mere existence of enterprises evidently does not reveal much about their business success, we introduced an additional variable to measure it: the annual cash flow of businesses.

In the present study we are going to analyse the role of social relations in the setup process of enterprises by the aid of a questionnaire survey of 3,021 respondents representative of the adult population of Transylvanian small towns, and study the impact of relationships on business success based on the results of a questionnaire survey of 1,005 companies representative of Transylvanian small and medium-sized enterprises. ${ }^{1}$

In the analysis we are going to take under close examination the structural characteristics of the ego-centered networks of individuals being in different stages of the entrepreneurial process. This research strategy is based on the idea that if there are differences to be detected in the characteristics of the individuals' social network, the underlying cause is a selection mechanism, as a result of which those individuals whose social network bears the characteristics of a later entrepreneurial phase are more succesful in progressing to the next phase of entrepreneurship (Greve, 1995).

\section{The studied types of relationships and their presumed effect on the different phases of becoming an entrepreneur and on entrepreneurial success}

In the present analysis, we are going to examine the prevalence rate of three types of relations: non-economic, personal relationships, functional personal relationships necessary for starting

${ }^{1}$ The survey on population was conducted by way of questionnaires completed in the respondents' homes in MayJune of 2011. The applied random sample was stratified by gender, age, nationality and county. Data collection on entrepreneurs was performed in the same period. This time the sample was stratified according to the size, activity area and the regional distribution of enterprises. For the survey on population the maximum margin of error was of $+/-1.8 \%$, at a $95 \%$ confidence level, and in the case of the entrepreneurial survey $+/-3.1 \%$. Both surveys were carried out as part of the research program entitled "Integrated Enterprise Development Model in the Small Towns of Three Development Regions" of the Research Center on Inter-Ethnic Relations from Cluj. 
and running an enterprise, as well as institutional relationships formed with the institutional environment of the enterprise.

Independently of the setting up of an enterprise, the personal relationships existing prior to entrepreneurial intentions may facilitate the success of entrepreneurship in two respects. On the one hand, as we have shown above, they may be the means of mobilizing various resources necessary for starting the business. In this respect, the more extensive and denser the social network, the greater the potential benefits as several researches have confirmed (GREVE 1995, etc). On the other hand, the personal relationship network acquires special importance, since it is well suited to convey direct information, know-how on entrepreneurship on ", entrepreneurial routine," if there are entrepreneurs, too, belonging to this network. In our research, we studied this function of personal social networks existing independently of the entrepreneurial intention, therefore, in the case of this network, we did not inquire about its structural characteristics (extent, density, etc.) but our questions pertained to whether the information concerning entrepreneurship is available through these relationships, that is, whether it is possible to reach other entrepreneurs through these ties. The effectiveness of this entrepreneurial knowledge transfer, however, may depend on the structural characteristics of the social network, its efficiency is subject to the nature of the relationship between the holder of entrepreneurial knowledge and the potential entrepreneur.

The importance of contacts with persons of different professions, relevant for the operation of the company, has been pointed out by several researchers, too (among others, the above discussed Greve). It is in any case inevitable for entrepreneurs to develop some of these types of relationships (for instance with an accountant). Besides these necessary connections, however, there is a wide variety of voluntary relationships developed on one's own initiative, which may help entrepreneurs to successfully found their business. Apart from conveying knowledge on „entrepreneurial routine," contacts with business leaders and entrepreneurs have other functions, too, since these persons are important members of the circle of suppliers and customers. There may be still further types of voluntary relationships, including some that seem to have so far escaped the attention of socio-economic researcher. We refer here to the relationships (possibly) connecting companies with the non-economic sector. Enterprises are embedded more or less also in the public sector through the orders they honour, and have tighter or looser relations with the state institution system through the bodies monitoring the activities of companies. These non-economic ties vary by country, and are likely to be stronger in countries with a socialist past. The role of controlling institutions is certainly influenced by the overall level of corruption (since these officials may easily obstruct the operation of an enterprise). For these reasons, we addressed in our research the issue of personal relations with those working in political-administrative institutions, as well as of the contacts formed with officials of institutions controlling the operation of enterprises.

Finally, we assessed the relations of enterprises with the institutional stakeholders of their economic environment. Here we intended to map those relationships of the enterprises that were not person-to-person relations, but contacts between the company and other institutions (organizations), irrespective of whether the connection was formal or informal. In this set of questions, on the one hand we inquired about relationships established with representative and consulting organizations (entrepreneur associations, cooperatives, business incubators, consulting firms), on the other hand, about relations with political and administrative institutions again. During processing, we considered these relationships also part of the ego-centered relationship network of the entrepreneur. 
Based on the above, we formulated the following hypotheses on the impact of the entrepreneurs' social network on his/her success in founding an enterprise:

The entrepreneurial routine conveyed by the personal relationship network existing independently of entrepreneurial intentions plays a decisive role in the process of entrepreneurship. Accordingly, in the case of entrepreneurs in later stages of setting up their business will have more and more entrepreneurs in their originally non-economic personal contact network

B1. Necessary functional relationships will gain importance in the planning phase of the process of becoming an entrepreneur. Afterwards there is no reason for the proliferation of relationships of this type, therefore, the prevalence of such relationships in the social network will not grow in this later stage.

B2. he relationships formed with business leaders and independent entrepreneurs are of the utmost importance in all phases of the life span of the enterprise, therefore, the prevalence of these relations is expected to increase continuously. Since beginning from the establishment phase these relationships gain a new, additional function, too, the prevalence of these contacts is expected to grow considerably in the last phase of the process.

B3. Personal relationships with the political and administrative sector and controlling institutions will become important in the establishment phase.

C1. Institutional relationships established with representative and consulting organizations gain real importance in the establishment phase.

C2. Institutional relationships with the political-administrative institutions also become important in the establishment phase.

D. In the case of already existing enterprises all the above discussed types of relationships promote entrepreneurial success.

\section{Analysis}

In the analysis of the process of setting up an enterprise thus we distinguish among four stages of the process. Since we are using here the results of a population-based survey, the vast majority of respondents, understandably, has never even considered the question of founding an enterprise (81.5\%). Those being in the motivational phase make up $11.1 \%$ of the respondents, those in the active phase $3.3 \%$, and $4.2 \%$ of all respondents were entrepreneurs or self-employed - they may be considered to have arrived to the establishment phase. Although the persons being in an advanced stage of entrepreneurship form only a relatively small proportion of respondents, the database has proved useful for the present purpose, thanks to the size of the sample.

A) We inquired about the entrepreneurial model conceived not for economic purposes, that is, the one to be found in the social network independent from the firm, within the framework of the nuclear family relations and contacts with relatives, neighbours and friends. As regards prevalence in this framework, we expected - in accordance with our hypothesis A. - that in the more advanced stages of entrepreneurship we would find a growing proportion of entrepreneurs. As shown in Table 1, this assumption proved only partly true. As concerns family relationships, spouses and siblings with entrepreneurial experience gain increasing importance as the entrepreneurial process progresses. The importance of parents with entrepreneurial experience does not grow after the motivation phase, but still, it continues to be important. 
The number of persons belonging to the network that covers more distant relations than family ties is probably larger, therefore, understandably, there is a higher percentage of entrepreneurs in these relations. Thus, the entrepreneurial model to be found in these relationships plays a greater role in the formation of motivation, but these relations fall back in importance during the operation of the established enterprise.

TABLE 1 *Were there entrepreneurs in your family, among your relatives and friends or their close relatives? ("YES" responses, in percentages)

\begin{tabular}{c|c|c|c|c} 
& $\begin{array}{c}\text { Not potential } \\
\text { entrepreneur }\end{array}$ & $\begin{array}{c}\text { Motivation } \\
\text { phase }\end{array}$ & $\begin{array}{c}\text { Planning } \\
\text { phase }\end{array}$ & $\begin{array}{c}\text { Establishment } \\
\text { phase }\end{array}$ \\
\hline \hline Spouse, partner & 2.9 & 7.1 & 14.7 & 17.8 \\
\hline Parent & 3.6 & 10.9 & 10.3 & 10.1 \\
\hline Sibling & 3.1 & 7.6 & 9.3 & 13.4 \\
\hline Neighbour & 10.1 & 20.2 & 25.8 & 13.8 \\
\hline Close friend & 14.6 & 30.5 & 42.3 & 37.7 \\
\hline Relative & 12.7 & 24.4 & 33.3 & 2.1
\end{tabular}

B) As regards the prevalence of relationships maintained with different occupational groups, our first hypothesis seems to prove true: the prevalence of relations with accountants, lawyers and notaries grows in the planning phase, but there is no significant growth in the establishment phase. The once established relationships, that are in most cases business-related, are maintained during the further existence of the enterprise, but the prevalence of this type of costly relationship will not exceed the necessary extent.

The situation is different as regards the prevalence of relations with business leaders and entrepreneurs, which continues to grow throughout the process of enterprise setup process. A specific dynamics of relationships with small entrepreneurs and self-employed persons may be observed, inasmuch as it changes twice dramatically throughout the business setup process. These relations are important conditions for stepping into the motivation phase, after which, during the transition to the planning phase, the prevalence of these relationships increases only slightly. Upon entering the establishment phase, however, the number of these relations shoots up.

Our hypothesis concerning political and administrative relations has not been confirmed. Although the prevalence of these relations shows a growing tendency up to the planning phase, in the establishment phase the prevalence of this relationship type decreases. This result indicates, therefore, that political and administrative relations have the greatest significance in the planning phase (providing consultancy services), and lose their importance in the case of already operating enterprises. The relations maintained with officials of the controlling institutions show a similar dynamics.

TABLE 2. *Do you have friends of the following professions? („Yes, we keep in touch regularly”-answers in percentages)

\begin{tabular}{c|c|c|c|c} 
& $\begin{array}{c}\text { Not potential } \\
\text { entrepreneur }\end{array}$ & $\begin{array}{c}\text { Motivation } \\
\text { phase }\end{array}$ & Planning phase & $\begin{array}{c}\text { Establishment } \\
\text { phase }\end{array}$ \\
\hline \hline Accountant & 13.4 & 22.7 & 45.3 & 46.8 \\
\hline Lawyer & 6.7 & 17.0 & 21.4 & 22.6 \\
\hline Notary & 4.3 & 5.7 & 16.1 & 13.0 \\
\hline
\end{tabular}




\begin{tabular}{c|c|c|c|c}
\hline Manager of a large-scale enterprise & 5.4 & 13.0 & 23.2 & 25.4 \\
\hline Small entrepreneur, manager & 10.7 & 28.1 & 31.6 & 44.3 \\
\hline Self-employed, family entrepreneur & 10.5 & 30.8 & 33.3 & 37.4 \\
\hline Local councilor, mayor & 5.3 & 11.4 & 22.9 & 16.0 \\
\hline County councilor, municipal official & 6.9 & 15.5 & 24.0 & 15.8 \\
\hline Local politician & 3.8 & 8.9 & 15.6 & 9.1 \\
\hline $\begin{array}{c}\text { County politician, national } \\
\text { politician }\end{array}$ & 2.4 & 4.8 & 10.8 & 9.8 \\
\hline $\begin{array}{c}\text { Control bodies officials } \\
\quad 2.8\end{array}$ & 7.7 & 13.7 & 13.1
\end{tabular}

C) Our hypothesis on the network of institutional relationships has also been confirmed only partially. The presumed dynamics of prevalence of relationships evolved in accordance with our expectations only as concerns the entrepreneurs' associations and other entrepreneurial organizations, showing a significant increase after reaching the establishment phase. The ties maintained with co-operatives show a steady growth during the entrepreneurial process, the services of consultant and proposal writing firms are employed to the greatest extent during the planning phase. The relations established with political-administrative institutions follow the above detailed dynamics of ties with politicians and public officials, that is, after entering the establishment phase these ties start to lose significance.

TABLE 3. Do you have contact with the following types of institutions? („Personal relationship”-answers in percentages

\begin{tabular}{c|c|c|c|c} 
& $\begin{array}{c}\text { Not potential } \\
\text { entrepreneur }\end{array}$ & $\begin{array}{c}\text { Motivation } \\
\text { phase }\end{array}$ & Planning phase & $\begin{array}{c}\text { Establishment } \\
\text { phase }\end{array}$ \\
\hline \hline $\begin{array}{c}\text { Entrepreneurs' Association, Chamber } \\
\text { of Commerce }\end{array}$ & 0.6 & 3.1 & 7.4 & 17.6 \\
\hline $\begin{array}{c}\text { Other entrepreneurial } \\
\text { organizations (eg. incubator) }\end{array}$ & 0.4 & 2.5 & 3.2 & 7.6 \\
\hline Co-operative (credit, sales, producer) & 1.0 & 4.1 & 7.4 & 10.9 \\
\hline $\begin{array}{c}\text { Business consultant and proposal } \\
\text { writing firm }\end{array}$ & 1.3 & 5.3 & 8.4 & 8.2 \\
\hline Municipality or county council & 9.3 & 11.6 & 21.1 & 20.2 \\
\hline Local or county party organization & 1.9 & 6.3 & 8.5 & 6.8
\end{tabular}

Finally, we are going to perform the analysis of the examined types of social capital, using the linear regression model. Before applying the regression model, the variables that may be combined in one factor have been aggregated by principal component analysis according to relationship type. This data reduction procedure and its results are summarized in Table 4. 
TABLE 4. The summary of the data reduction procedure.

\begin{tabular}{|c|c|c|}
\hline Set of questions & Factors & Variables included in the factors \\
\hline \multirow{6}{*}{$\begin{array}{l}\text { The presence of the } \\
\text { entrepreneurial model in non- } \\
\text { economic personal relationships }\end{array}$} & \multirow{3}{*}{ Family ties } & Spouse \\
\hline & & Parent \\
\hline & & Sibling \\
\hline & \multirow{3}{*}{$\begin{array}{l}\text { Relationships in the broader } \\
\text { personal environment }\end{array}$} & Friend \\
\hline & & Neighbour \\
\hline & & Relative \\
\hline \multirow{9}{*}{ Functional relationships } & \multirow{4}{*}{ Factor of economic relations } & $\begin{array}{c}\text { Small entrepreneur / Small-enterprise } \\
\text { manager }\end{array}$ \\
\hline & & Self-employed, family entrepreneur \\
\hline & & Accountant \\
\hline & & Large-scale entrepreneur / Manager \\
\hline & \multirow{5}{*}{$\begin{array}{l}\text { Factor of personal-level } \\
\text { political-administrative } \\
\text { relations }\end{array}$} & Politician in the local party organization \\
\hline & & $\begin{array}{c}\text { Politician in the county or national party } \\
\text { organization }\end{array}$ \\
\hline & & Local or county municipality official \\
\hline & & Local or county councilor \\
\hline & & Supervisory official \\
\hline \multirow{6}{*}{$\begin{array}{l}\text { Institutional network of } \\
\text { relationships }\end{array}$} & \multirow{4}{*}{$\begin{array}{l}\text { Factor of institution-level } \\
\text { economic relations }\end{array}$} & Business consulting company \\
\hline & & Co-operatives \\
\hline & & Entrepreneurial associations, incubators \\
\hline & & Entrepreneurial cluster \\
\hline & \multirow{2}{*}{$\begin{array}{l}\text { Factor of institution-level } \\
\text { political-administrative ties }\end{array}$} & Local or county municipality \\
\hline & & Local or county party organization \\
\hline
\end{tabular}

The impact of the resulting six factors has been tested step by step for each phase of becoming an entrepreneur. Table 5. summarizing the results also indicates the tendencies outlined above: the entrepreneurial model associated with the personal social network is more important in the motivation and planning phase, later its importance decreases. By contrast, the significance of the entrepreneurial model associated with the family social network grows in this latter phase. Personal economic ties become increasingly important during the progress of the process, as well as the ties formed with economic institutions. Relations established with the officials of politicaladministrative controlling institutions, though they initially bear a significant impact on the process of becoming an entrepreneur, later, in the establishment phase, they lose significance. Institutional ties formed with this sphere do not have a significant impact on any of the phases of becoming an entrepreneur.

TABLE 5. The effect of the social network on the entrepreneurship process, divided into phases.

\begin{tabular}{c|c|c|c|c|c|c} 
& \multicolumn{2}{|c|}{ Motivation phase } & \multicolumn{2}{c|}{ Planning phase } & \multicolumn{2}{c}{$\begin{array}{c}\text { Establishment } \\
\text { phase }\end{array}$} \\
\hline \hline & Beta & Sig. & Beta & Sig. & Beta & Sig. \\
\hline $\begin{array}{c}\text { Entrepreneurs in the larger } \\
\text { personal social network }\end{array}$ & 0.055 & 0.012 & 0.081 & 0.000 & $\mathrm{x}$ & $\mathrm{x}$ \\
\hline
\end{tabular}




\begin{tabular}{c|c|c|c|c|c|c}
\hline $\begin{array}{c}\text { Entrepreneurs in the } \\
\text { family social network }\end{array}$ & 0.065 & 0.002 & 0.062 & 0.002 & 0.120 & 0.000 \\
\hline Economic relations & 0.137 & 0.000 & 0.176 & 0.000 & 0.222 & 0.000 \\
\hline $\begin{array}{c}\text { Personal-level political- } \\
\text { administrative ties }\end{array}$ & 0.053 & 0.016 & 0.094 & 0.000 & 0.057 & 0.006 \\
\hline $\begin{array}{c}\text { The factor of economic } \\
\text { institutions }\end{array}$ & 0.111 & 0.000 & 0.116 & 0.000 & 0.149 & 0.000 \\
\hline $\begin{array}{c}\text { Political-administrative } \\
\text { institutions }\end{array}$ & $\mathrm{x}$ & $\mathrm{x}$ & $\mathrm{x}$ & $\mathrm{x}$ & $\mathrm{x}$ & $\mathrm{x}$
\end{tabular}

D) The analysis of the relation between social networks and entrepreneurial success, is performed, unlike the above, not based on a survey on population, but on the basis of the results of a survey on enterprises. Due to the larger sample size, this entrepreneurial database allows for a more reliable analysis, though it presents a significant disadvantage, too, inasmuch as the respondents in most cases are the managers of the enterprises, and not the actual entrepreneurs themselves, as it has been mentioned in the methodological presentation of the research. Thus, the results may be regarded as to confirm or refute our hypothesis only inasmuch as the analysed social networks may be considered to be the company's social network, and not the personal social network of the entrepreneur or manager.

We have studied the influence of relations on the successful operation of an enterprise, applying the research strategy used so far. We have grouped enterprises, according to the time elapsed since their foundation, into two categories: enterprises in the initial and in a later phase of their operation, drawing the boundary between these two categories at four years from the beginning of their operation. We have examined the correlation between the different types of relations and the two categories of enterprises, by the aid of contingency tables. The results are presented in Table 6.

As shown in Table 6, there are very few significant relationships between the time elapsed since the founding of the enterprise and the different features of the social network. The existing personal relationships with entrepreneurs that constituted an important factor in the process of founding the enterprise, ceased to influence its successful operation after the founding stage. Similarly, there is no significant difference between the initial phase and the later phases of operation as regards the prevalence of institutional relations either. Significant differences between the two categories of enterprises have been found only in the case of some functional relationships with the officials of political-administrative institutions, as well as controlling bodies.

TABLE 6. The impact of contact types on the successful operation of enterprises

\begin{tabular}{|c|c|c|c|}
\hline & \multicolumn{2}{|c|}{ The enterprise has been operating for } & \multirow[b]{2}{*}{ Sign. } \\
\hline & Less than four years & $\begin{array}{c}\text { More than four } \\
\text { years }\end{array}$ & \\
\hline \multicolumn{4}{|c|}{ There is an entrepreneur among the following persons } \\
\hline Spouse, partner & 16.7 & 19.7 & $\mathrm{x}$ \\
\hline Father & 6.4 & 7.5 & $\mathrm{x}$ \\
\hline Mother & 5.5 & 3.9 & $\mathrm{x}$ \\
\hline Siblings & 8.3 & 10.1 & $\mathrm{x}$ \\
\hline
\end{tabular}




\begin{tabular}{|c|c|c|c|}
\hline Neighbour & 16.0 & 16.0 & $\mathrm{x}$ \\
\hline Relative & 25.5 & 25.3 & $\mathrm{x}$ \\
\hline Close friends & 42.6 & 38.5 & $\mathrm{x}$ \\
\hline \multicolumn{4}{|l|}{$\begin{array}{l}\text { There is a member of one of the following } \\
\text { professions among acquaintances }\end{array}$} \\
\hline Small-enterprise manager & 89.2 & 89.2 & $\mathrm{x}$ \\
\hline Manager of a large-scale enterprise & 70.9 & 72.2 & $\mathrm{x}$ \\
\hline Accountant & 92.0 & 94.5 & $\mathrm{x}$ \\
\hline Notary & 68.8 & 72.3 & $\mathrm{x}$ \\
\hline Self-employed, family entrepreneur & 78.4 & 84.8 & 0.059 \\
\hline Lawyer & 69.6 & 77.0 & 0.057 \\
\hline Politician in the county or national party organization & 30.4 & 37.8 & 0.075 \\
\hline Mayor, local or county councilor & 58.9 & 68.7 & 0.026 \\
\hline Politician in the local party organization & 41.4 & 52.6 & 0.017 \\
\hline Municipal or county council official & 58.9 & 71.0 & 0.007 \\
\hline Control bodies official & 33.3 & 46.5 & 0.005 \\
\hline \multicolumn{4}{|l|}{ Direct relations with the following institutions } \\
\hline Consulting company & 8.2 & 11.9 & $\mathrm{x}$ \\
\hline Co-operative & 5.4 & 4.9 & $\mathrm{x}$ \\
\hline Business associations, chambers of commerce & 9.0 & 13.3 & $\mathrm{x}$ \\
\hline Entrepreneurial network, cluster & 3.0 & 6.5 & $\mathrm{x}$ \\
\hline Municipality, county council & 20.5 & 20.3 & $\mathrm{X}$ \\
\hline Local and county party organization & 6.4 & 5.4 & $\mathrm{X}$ \\
\hline
\end{tabular}

We used the business turnover as another operationalization possibility of entrepreneurial success. We did not distinguish between categories according to the size of the turnover. instead, we compared the average turnover according to relation types. With this method we haven't found any significant correlations between turnover and functional relationships, therefore we left out these correlations from Table 7., which summarizes the results. Ties to / Relations with the entrepreneurs belonging to the personal social network do not exert a significant effect on entrepreneurial success, although the presence of a entrepreneur spouse or parent increases turnover almost significantly. In contrast with personal and functional relations, however, we have found a significant correlation between institutional ties and turnover. These ties increased the turnover of the enterprise in all cases.

TABLE 7. The averages of company turnover according to the types of business relationships

\begin{tabular}{c|c|c|c} 
& Yes & No & Sign. \\
\hline \hline $\begin{array}{c}\text { There is an entrepreneur among the following } \\
\text { persons }\end{array}$ & & & \\
\hline Spouse, partner & 593876175 & 170437916 & 0.076 \\
\hline Father & 792101141 & 189833926 & 0.056 \\
\hline
\end{tabular}




\begin{tabular}{|c|c|c|c|}
\hline Mother & 4522774 & 258041126 & $\mathrm{x}$ \\
\hline Siblings & 206407126 & 251746043 & $\mathrm{x}$ \\
\hline Neighbour & 102617063 & 286531591 & $\mathrm{x}$ \\
\hline Relative & 459339364 & 204371461 & $\mathrm{x}$ \\
\hline Close friend & 248368176 & 258301017 & $\mathrm{x}$ \\
\hline \multicolumn{4}{|l|}{ Direct relations with the following institutions } \\
\hline Consulting company & 721870699 & 107593885 & 0.007 \\
\hline Co-operative & 858658915 & 145010357 & 0.020 \\
\hline Business associations, chambers of commerce & 690222548 & 116605112 & 0.012 \\
\hline Entrepreneurial network, cluster & 929489810 & 141533423 & 0.007 \\
\hline Municipality, county council & 496809996 & 115640340 & 0.053 \\
\hline Local and county party organization & 834247679 & 161821488 & 0.031 \\
\hline
\end{tabular}

To study the joint impact of the different types of relationship on entrepreneurial success, we aggregated these relationships by principal component analysis. As a result, the personal contacts with entrepreneurs before becoming one of them settled into three factors (the friends-neighboursrelatives factor, the parents' factor and the spouse-sibling factor); functional relationships settled also into three factors (the factors of political-administrative-bureaucratic relations, of those established with small entrepreneurs-self-employed-accountants, as well as the factors of ties formed with notaries-lawyers-big entrepreneurs), whereas institutional relationships combined into a single factor Examining by means of the regression model the relationship between these factors and the number of years elapsed since the founding of the enterprise, as well as the company's cash flow - as it was expected in view of the results above - we could not find any association. Az regards also the correlation between the two variables of individual factors and success, we could find a weak correlation in the case of one single factor: between the factor of institutional relations and the company's cash flow.

TABLE 8. Thecorrelationbetweenfactorsformed oftypesofrelationshipsandentrepreneurialsuccess(correlationcoefficients)

\begin{tabular}{|c|c|c|c|c|}
\hline & \multicolumn{2}{|c|}{$\begin{array}{l}\text { The time elapsed since the } \\
\text { founding of the enterprise }\end{array}$} & \multicolumn{2}{|c|}{ The company's turnover } \\
\hline & $\begin{array}{c}\text { Pearson } \\
\text { coefficient }\end{array}$ & Sig. & $\begin{array}{l}\text { Pearson } \\
\text { coefficient }\end{array}$ & Sig. \\
\hline Entrepreneur among friends, neighbours, relatives & 0.026 & 0.457 & 0.006 & 0.915 \\
\hline $\begin{array}{l}\text { Entrepreneur parent } \\
\text { Vállalkozó a szülök között }\end{array}$ & -0.053 & 0.124 & -0.057 & 0.284 \\
\hline Entrepreneur spouse or sibling & -0.002 & 0.948 & -0.052 & 0.323 \\
\hline Political-administrative-bureaucratic ties & -0.046 & 0.164 & 0.028 & 0.584 \\
\hline $\begin{array}{l}\text { Relations with small and self-employed } \\
\text { entrepreneurs, accountants }\end{array}$ & 0.027 & 0.419 & 0.057 & 0.253 \\
\hline $\begin{array}{c}\text { Relations with notaries, lawyers, large-scale } \\
\text { entrepreneurs }\end{array}$ & -0.032 & 0.330 & -0.044 & 0.383 \\
\hline Institutional relations & 0.014 & 0.669 & $-0.117^{*}$ & 0.018 \\
\hline
\end{tabular}




\section{Conclusions}

Our results thus indicate that the nature of the social network is changing during the process of entrepreneurship, that is, the entrepreneur will utilize different types of social relations as a resource in the different successive stages of setting up the enterprise. Thus, the entrepreneurial models offered by the personal network of contacts, the presence of other entrepreneurs in these close personal relationships, are important factors in becoming an entrepreneur, and they become increasingly important as the process progresses, losing some of their significance only after the establishment of the enterprise. But even in this case, it may have a relatively important positive impact on the company's turnover if the entrepreneur's spouse or parent is also an entrepreneur. Similarly, functional relationships also play an increasingly important role in the process of entrepreneurship, in the established operational phase, however, these relations are no longer the conditions for further business success, their prevalence does not increase further. This applies primarily to economic, service-related ties. Political-administrative relations retain their importance during operation, thus contributing to entrepreneurial success.

Institutional relations gain importance progressively in the course of the life of the enterprise. In the initial stages of business setup (the motivation and planning phase) only the contacts formed with economic institutions are important, at this stage the political-administrative relations do not contribute to the consolidation of the business. In the later phase of the life span of the enterprise, however, these relations are the ones that contribute the most to entrepreneurial success. On the basis of these results, the overall conclusion is that the social network as a resource is much more important during the setting up of an enterprise, whereas in the case of already established, operating enterprises its contribution to entrepreneurial success is less significant than expected.

\section{BIBLIOGRAPHY}

Aldrich, H.E. - Zimmer, C. (1986): Enterpreneurship through Social Networks. In Aldrich, Howard E.(ed.): Population Perspectives on Organisations. Uppsala: Acta Universitatis Upsaliensis. 13-28.

Bates, Тімотну (1994): Social Resources Generated by Group Support Networks May Not Be Beneficial to Asian Immigrant-Owned Small Businesses. Social Forces vol. 72. no. 3. 671-689.

Brüderl Josef - Preisendörfer Peter (1998): Network Support and the Success of Newly Founded Businesses. Small Business Economics vol. 10. no. 3. 213-225.

Curra James - Jarvis Robin - Blackburn Robert A. - Black Sharon (1993): Networks and Small Firms: Constructs, Methodological Strategies and Some findings. International Small Business Journal vol. 11. no. 2. 13-25.

DonkCels, RiK - Lambrecht, Johan (1995): Networks and Small Business Growth: an Explanatory Model. Small Business Economics vol. 7. issue 4. 273-289.

Dubini, Paola - Aldrich, Howard E. (1991): Personal and Extended Networks are Central to the Enterpreneurial Process. Journal of Business Venturing 6. no. 5. 305-313

Greve, Arent (1995): Networks and Enterpreneurship. An Analysis of Social Relations, Occupational Background, and Use of Contacts During the Establishment Process. Scandinavian Journal of Management vol. 11. no.1, 1-24.

Kuczi, Tibor (2011): Kisvállalkozás és társadalmi környezet. Jelenkutató Alapítvány, Budapest.

Pete, Stefan - Nagy, Ágnes - Györfy, Lehel-Zoltán - Benyovszki, Annamária - Petru, Tünde Petra (2010): Evoluția factorilor de influență ai activității antreprenoriale în stadiu incipient din România. Economie teoretică şi aplicată vol. 17. no. 7. (548). 3-12

SAnders, Jiny M. - NeE, Victor (1996): Immigrant Selfemployment: The Family as Social Capital and the Value of Human Capital. American Sociological Review vol. 61. no. 2. 674-698. 